\title{
A NOVEL METHOD FOR THE EXTRACTION OF THE MAIN COMPOUNDS FROM THE ESSENTIAL OIL OF CLOVE BUDS
}

\author{
NIKOLAY N. BOYKO ${ }^{1 \mathrm{a}, \mathrm{b} *}$, ELENA T. ZHILYAKOVA ${ }^{\mathrm{1}}$, DMITRIY I PISAREV ${ }^{2}$, OLEG O. \\ NOVIKOV $^{2}$, RITA V. SAHAIDAK-NIKITIUK ${ }^{3 a}$, VICTORIA YU. KUZNIETSOVA ${ }^{3 b}$, OLEG S. \\ SHPYCHAK $^{3 c}$, ALEKSANDR V. TKACHEV $^{4 a}$, ANATOLIY M. KOVALENKO $^{4 \mathrm{~b}}$, NATALIA A. \\ SUSHCHUK $^{5}$
}

\begin{abstract}
${ }^{1}$ Laboratory of Technology of Drugs ${ }^{a}$, Department of Pharmaceutical Technology ${ }^{b}$, Department of General Chemistry ${ }^{c}$, Belgorod National Research University, 85 Pobedy Street, Belgorod, Russia

'Shared Knowledge Center (Research and Educational Center) 'Drugs' quality control center" Peoples' Friendship University of Russia, 8/2 Miklukho-Maklay Street, Moscow, Russia

${ }^{3}$ Department of Processes and Apparatuses of Chemical and Pharmaceutical Industries ${ }^{a}$, Department of Chemistry of Natural Compounds ${ }^{b}$, Department of Industrial Pharmacy and Economy Institute for Advanced Training of Pharmacy Specialists ${ }^{c}$ of National University of Pharmacy, 53 Pushkinska Street, Kharkiv, Ukraine

${ }^{4}$ Department of General and Private Zootechnics ${ }^{a}$, Department of Infectious and Invasive Pathology ${ }^{b}$, Belgorod State Agricultural University named after V. Gorin, Federal State Budgetary Educational Institution of Higher Education, 3 Vavilova Street, Belgorod, Russia

${ }^{5}$ Department of Technology of Drugs, Odessa National Medical University, 2 Valikhovsky Lane, Odessa, Ukraine
\end{abstract}

*corresponding author: boykoniknik@gmail.com

Manuscript received: July 2019

\begin{abstract}
The purpose of this work was to test a hypothesis about the possibility of extraction of the main clove buds essential oil substances from with two different types of perfluoro organic solvents, Novec 1230 and Novec 7100. Using simple maceration method, it was found out that the maximum yield of eugenol was observed into $n$-hexane: $81 \pm 4 \%$. The yield of eugenol into perfluoro organic solvent Novec 7100 was $73 \pm 4 \%$ and into the perfluoro organic solvent Novec 1230 was $6.9 \pm$ $0.4 \%$. Using the extraction circulation method, it was found that the yield of eugenol into perfluoro organic solvent Novec 7100 in $2 \mathrm{~h}$ of circulation was $85 \pm 4 \%$. Under the same conditions, the yield of eugenol into the perfluoro organic solvent Novec 1230 was $54 \pm 3 \%$ during $4 \mathrm{~h}$ of its circulation.
\end{abstract}

\section{Rezumat}

Scopul acestei lucrări a fost de a testa ipoteza cu privire la posibilitatea extracției substanțelor principale din uleiul esențial de cuişoare cu două tipuri diferite de solvenți organici, Novec 1230 şi Novec 7100. Folosind metoda macerării simple, s-a constatat că randamentul maxim de obținere a eugenolului a fost în n-hexan: $81 \pm 4 \%$. Randamentul de obținere a eugenolului în solventul organic perfluoric Novec 7100 a fost de $73 \pm 4 \%$ și cel în Novec 1230 a fost de $6,9 \pm 0,4 \%$. Utilizând metoda extractivă de circulație, s-a constatat că randamentul eugenolului în solventul organic perfluoric Novec 7100 , în 2 ore de circulație, a fost de $85 \pm 4 \%$. În aceleași condiții, randamentul eugenolului în solventul organic perfluoric Novec 1230 a fost de $54 \pm 3 \%$ în timpul a 4 ore de circulație.

Keywords: eugenol, clove buds, Novec 1230, Novec 7100

\section{Introduction}

Caryophyllus aromaticus L. tree is a perennial and evergreen plant that belongs to Myrtaceae family. Clove buds are plant raw material (PRM) used in medicinal, perfume, food and liquor industries.

The main constituents of clove buds are essential oil up to $20 \%$ (eugenol up to $85 \%$, eugenyl acetate up to $15 \%$, caryophyllene up to $4 \%$, etc.), galotanins up to $2 \%$, flavonoids (derivatives of quercetin, eugenitin, eugenin, biflorin, myricetin, etc.), phytosterols (campesterol, stigmasterol), triterpenic saponins (crategolic and oleanolic acids), microelements, etc. [12, 13, 17].
Biologically active substances (BAS) from clove buds have different useful pharmacological activities such as analgesic, anti-ulcerogenic, antiinflammatory, antimicrobial, antifungal, antioxidant, antitumor, antidiabetic, cardioprotective, hepatoprotective, etc. [1, 2, 13, 14, 16-18, 20, 24]. Furthermore, some biologically active substances exhibit low toxicity [2, 14, 23].

Therefore, one of the promising areas of focus for the development of drugs from this type of PRM is the development of galenical drugs in the form of a tincture or an extract $[13,14]$. Another promising area of focus is a step-by-step treatment of PRM and the 
obtainment of lipophilic and hydrophilic extracts from it. The treatment of PRM with liquefied gases and liquids in the supercritical state (supercritical fluids) is considered to be a very promising technology all over the world [5, 8, 9, 11, 15, 19]. Moreover, extraction of essential oil and eugenol from clove buds with supercritical fluids (in general, carbon dioxide) and/or liquefied gases have been successfully studied by different scientists [6, 9, 12, 15, 25].

The main advantages of these technologies are the following: minimal temperature, it can be organized step-by-step extraction of various types of BAS with different polarity, environment-friendly, fire and explosion-proof, they require minimal energy $[7,10$, 11]. At the same time, these technologies have certain disadvantages: they require the use of special and

expensive equipment that can perform under pressure and the use of a refrigerator.

In the light of the research, we focused our attention on unique physical and chemical properties of some freons and perfluoro organic solvents, for example, perfluorocyclobutane (RC318). Freons and perfluoro organic solvents have the lowest values for key and important physical and chemical parameters, such as heat of vaporization, surface tension, the boiling point. They are fire and explosion-proof, as well as lowtoxic. But the most important thing is that these solvents are characterized by hydrophobicity of various degree and even lipophobicity [10, 11, 22]. Physicochemical, ecological, and toxicological parameters of some perfluoro organic solvents and liquefied gases are presented in Table I [10, 11, 22].

Table I

Physicochemical, ecological, and toxicological parameters of some perfluoro organic solvents and liquefied gases

\begin{tabular}{|l|c|c|c|c|c|c|c|c|}
\hline \multirow{2}{*}{ Parameter } & \multicolumn{7}{c|}{ Solvent } \\
\cline { 2 - 9 } & $\begin{array}{c}\text { Novec } \\
\mathbf{1 2 3 0}\end{array}$ & $\begin{array}{c}\text { Novec } \\
\mathbf{7 1 0 0}\end{array}$ & Novec 7200 & $\begin{array}{c}\text { Vertrel XF } \\
(\mathbf{H F C} \text { 43-10 mee) }\end{array}$ & Perfluorohehane & R227ea & RC318 & CO2 \\
\hline Empirical formula & $\mathrm{C}_{6} \mathrm{~F}_{12} \mathrm{O}$ & $\mathrm{C}_{4} \mathrm{~F}_{9} \mathrm{OCH}_{3}$ & $\mathrm{C}_{4} \mathrm{~F}_{9} \mathrm{OC}_{2} \mathrm{H}_{5}$ & $\mathrm{C}_{5} \mathrm{H}_{2} \mathrm{~F}_{10}$ & $\mathrm{C}_{6} \mathrm{~F}_{14}$ & $\mathrm{C}_{3} \mathrm{~F}_{7} \mathrm{H}_{2}$ & $\mathrm{cC}_{4} \mathrm{~F}_{8}$ & $\mathrm{CO}_{2}$ \\
\hline Molecular weight, g/mol & 316 & 250 & 264 & 252 & 338 & 170 & 200 & 44 \\
\hline Pressure $20^{\circ} \mathrm{C}, \mathrm{MPa}$ & 0.040 & 0.027 & 0.016 & 0.030 & - & 0.391 & 0.272 & 6.0 \\
\hline Boiling point, ${ }^{\circ} \mathrm{C}$ & 49 & 61 & 76 & 55 & 57 & -16.4 & -5.8 & -78.5 \\
\hline Heat of vaporization, $\mathrm{kJ} / \mathrm{kg}$ & 88 & 112 & 119 & 130 & 91 & 133 & 117 & 155 \\
\hline Density $20^{\circ} \mathrm{C}, \mathrm{kg} / \mathrm{m}^{3}$ & 1,600 & 1,510 & 1,430 & 1,580 & 1,670 & 1,407 & 1,517 & 930 \\
\hline $\begin{array}{l}\text { Global warming potential } \\
(\text { GWP) }\end{array}$ & 1 & 320 & 55 & 1,650 & $7,400-9,300$ & 3,300 & 10,300 & 1 \\
\hline $\begin{array}{l}\text { Ozone depletion potential } \\
\text { (ODP) }\end{array}$ & 0 & 0 & 0 & 0 & 0 & 0 & 0 & 0 \\
\hline Toxicity, ppm & 4,000 & 750 & - & 200 & 71 & 1,000 & 1,000 & 5,000 \\
\hline
\end{tabular}

As presented in Table I, among different types of perfluoro organic solvents, two of them (Novec 1230 and Novec 7100) have promising physicochemical, ecological, and toxicological parameters.

These properties are determined by the presence of a special type intermolecular fluorine bond between perfluoro organic molecules [3].

Lipophobic properties in perfluoro organic solvents described in literature gave us the idea that these solvents may be used in phytotechnology for selective extraction of essential oils' components from the essential oil-bearing PRM [9]. Moreover, their use can be a good alternative for technology using liquid gases and/or supercritical fluids (presented in Table I). Thus, studies in the field of perfluoro organic solvents' use for extraction of different lipophilic BAS and essential oils, in particular, are rather pressing.

The purpose of this work was to test a hypothesis about the possibility of extraction of main essential oil substances from clove buds with two different types of perfluoro organic solvents, Novec 1230 and Novec 7100.

\section{Materials and Methods}

\section{Plant raw material}

For the study, we used milled clove buds with the particle size ranging from 0.1 to $0.5 \mathrm{~mm}$. PRM was acquired from "Lechec", Kharkiv, Ukraine; it is dated 08/2018.

\section{Chemicals}

Novec 1230, Novec 7100 (3M company, USA), and n-hexane (chemically pure grade, ComponentReactive, Russia) were used as solvents. As a reference substance, we used eugenol Sigma-Aldrich, Merck, content $\geq 99.0 \%$, CAS 97-53-0.

\section{Methods of extraction}

Simple maceration was carried out under the following conditions: $1.0 \mathrm{~g}$ of milled PRM (precisely weighed amount) was placed into a flask, then we added $10.0 \mathrm{~mL}$ of solvent and weighted for better accuracy, and then the flask was corked and macerated at $24 \pm$ $1{ }^{\circ} \mathrm{C}$ for $24 \mathrm{~h}$. After maceration, the extract was decanted and centrifuged at 3,000 rpm for $10 \mathrm{~min}$. The circulation method of extraction was carried out under the following conditions: $5.0 \mathrm{~g}$ of milled PRM (precisely weighed amount) was placed into the Soxhlet extractor, then $25.0 \mathrm{~mL}$ of the solvent were added, 
and the process of solvent circulation was carried out for a specified period.

The solvent was evaporated on the water-bath at $65^{\circ} \mathrm{C}$, and the extract obtained was dissolved in $10.0 \mathrm{~mL}$ of ethyl acetate weighted for better accuracy and analysed for a non-volatile residue of lipophilic substances by gravimetry and for eugenol content by reverse phase high performance liquid chromatography (RP HPLC) analysis.

The content of non-volatile residue of lipophilic substances was determined at the room temperature by gravimetry using method 3 from the general monograph "Loss on drying" of the State Pharmacopeia of the Russian Federation [21].

The eugenol content was analysed by RP HPLC method under the following conditions: $1.0 \mathrm{~mL}$ (precisely weighed amount) of ethyl acetate solution was dissolved in $10.0 \mathrm{~mL}$ of ethanol $96 \% \mathrm{v} / \mathrm{v}$.

GC-MS method of analysis

Qualitative analysis of extracts was carried out by GC-MS method using equipment GCMS-QP2010
Ultra with a mass analyser, by Shimadzu, Japan. Column: Zebron ZB-5MS, length $30 \mathrm{~m}$, inside diameter $0.25 \mathrm{~mm}$, film thickness $0.25 \mu \mathrm{m}$; liquid phase: 5\%-polysilarylene and 95-polydimethyl-siloxane; temperature settings: from $70^{\circ} \mathrm{C}$ to $325 / 350^{\circ} \mathrm{C}$. Gascarrier: helium with a stable flow of $3.0 \mathrm{~mL} / \mathrm{min}$. Detection regimen: total ion current (SCAN) in the range $\mathrm{m} / \mathrm{z}$ from 30 to $500 \mathrm{Da}$ with scanning velocity 1,000 and result time $0.5 \mathrm{sec}$. The injection volume was $1 \mu \mathrm{L}$.

\section{RP HPLC method of analysis}

Quantitative analysis of eugenol in the extracts was carried out by RP HPLC method using Agilent Technologies equipment, Agilent 1200 Infinity series, the USA. RP HPLC analysis conditions were the same as in the work of Zhilyakova et al. [26].

Suitability and validation parameters of the chromatographic method

The main parameters of the validation method of analysis and suitability of RP HPLC system for determination of eugenol are presented in Table II.

Table II

Main parameters of the validation method of analysis and suitability of RP HPLC system for determination of eugenol

\begin{tabular}{|l|c|c|}
\hline Parameter & Pharmacopoeia limitation [21] & Eugenol* \\
\hline Retention time $\left(\mathrm{t}_{\mathrm{R}}\right), \mathrm{min}$ & - & $29.8 \pm 1.0$ \\
\hline Asymmetry coefficient $(\mathrm{T})$ & $\leq 2.0$ & 0.84 \\
\hline Separation coefficient $\left(\mathrm{R}_{\mathrm{s}}\right)$ & $\geq 1.5$ & 24.0 \\
\hline Theoretical plates number $(\mathrm{N})$ & $\geq 1000$ & 232,400 \\
\hline RSD of peak's area, \% & $\leq 2.0$ & 1.6 \\
\hline LOD, g/mL & - & $7.8 \cdot 10^{-5}$ \\
\hline LOQ, g/mL & - & $2.4 \cdot 10^{-4}$ \\
\hline Determination coefficient, $r^{2}$ & $\geq 0.99$ & 0.9999 \\
\hline Calibration linear equation, $C(\mathrm{~g} / \mathrm{mL})=f(S(\mathrm{mAU} \cdot \mathrm{s}))$ & - & $C=(6.42 \pm 0.10) \cdot 10^{-7} \cdot \mathrm{S}$ \\
\hline
\end{tabular}

$*$ Note. The mean value and its confidence interval (Mean \pm SEM) are calculated with repeat counts $\mathrm{n}=3$ and significance level $\mathrm{p}=0.95$

\section{Results and Discussion}

The results of eugenol yield into n-hexane and perfluoro organic solvents Novec 1230 and Novec 7100 from the PRM are presented in Figure 1.

As can be seen from Figure 1, the largest yield of eugenol was found for $n$-hexane that equals $81 \pm 4 \%$, the yield for perfluoro organic solvent Novec 7100 is $73 \pm 4 \%$, and the lowest value of yield is found for Novec 1230 which equals $6.9 \pm 0.4 \%$.

These results indicate that eugenol yield from PRM into the perfluoro organic solvent depends significantly on the degree of its molecule fluorination; as Novec 7100 has a methoxy-group, makes this solvent in terms of the dissolving ability similar to n-hexane. At the same time, the molecule of Novec 1230 is fully fluorinated, which cause the maximum level of lipophobicity and hydrophobicity and explained the low yield of eugenol into this type of perfluoro organic solvent.

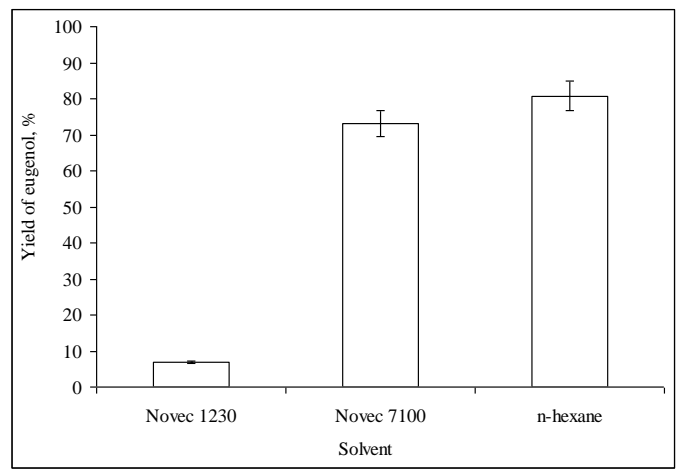

Figure 1.

The yield of eugenol maceration from PRM into different solvents. PRM:extractant ratio 1:10 w/v, temperature $24 \pm 1^{\circ} \mathrm{C}$, time of maceration $24 \mathrm{~h}$. Repeat counts $n=3$, significance level $p=0.95$

Figures 2 and 3 present qualitative data of GC-MS profiles of the extracts obtained with perfluoro organic solvents Novec 1230 and Novec 7100. 


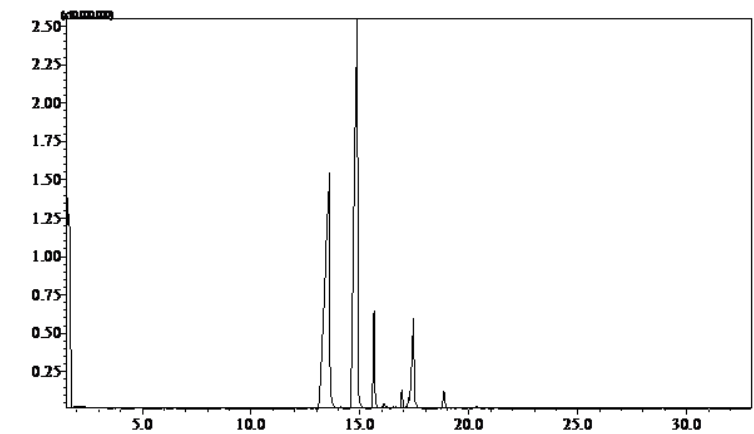

Figure 2.

A typical GC-MS profile of Novec 1230 extract.

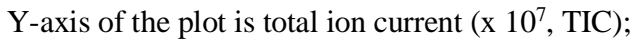
$\mathrm{X}$-axis of the plot is time, min

As can be seen in Figures 2 and 3, GC-MS chromatogram profiles of both extracts are similar; moreover, four substances are dominant (eugenol, caryophyllene, humulene, and eugenyl acetate).

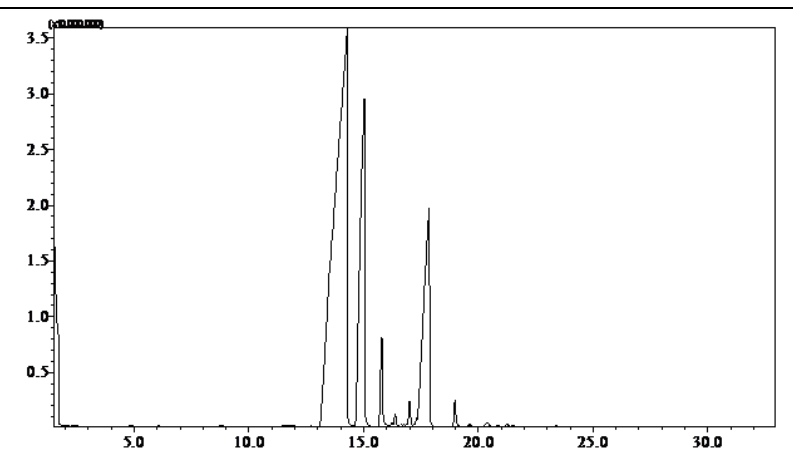

Figure 3.

A typical GC-MS profile of Novec 7100 extract. Y-axis of the plot is total ion current (x 107, TIC); $\mathrm{X}$-axis of the plot is time, $\min$

Results of extracts' analysis by GC-MS method are presented in Table III.

Table III

Content of Novec 1230 and Novec 7100 extracts

\begin{tabular}{|c|c|c|c|c|c|}
\hline \multirow{2}{*}{ No. } & \multirow{2}{*}{ Compound } & \multirow{2}{*}{ Retention time, min } & \multicolumn{2}{|c|}{ Percentage of the compound peak in the mixture, \%* } & \multirow{2}{*}{ Similarity, \% } \\
\cline { 4 - 5 } & & & Novec 1230 & Novec 7100 & \\
\hline 1 & Eugenol & $13.6 \pm 0.7$ & $39.0 \pm 2.0$ & $61.4 \pm 3.1$ & 96 \\
\hline 2 & Caryophyllene & $14.9 \pm 0.8$ & $43.4 \pm 2.2$ & $18.0 \pm 0.9$ & 95 \\
\hline 3 & Humulene & $15.7 \pm 0.8$ & $5.7 \pm 0.3$ & $2.3 \pm 0.1$ & 97 \\
\hline 4 & Eugenyl acetate & $17.5 \pm 0.9$ & $9.5 \pm 0.5$ & $16.4 \pm 0.8$ & 95 \\
\hline
\end{tabular}

$*$ Note. The mean value and its confidence interval (Mean \pm SEM) are calculated with repeat counts $n=3$ and significance level $p=0.95$

As can be seen from data of Table III, identical substances are present in both extracts, but we can see a different ratio of components caused by polar part (number of oxygen atoms) in their molecule and the degree of solvent molecule fluorination. The lesser number of oxygen atoms in BAS molecule (for example in caryophyllene and humulene they are absent) the better this molecule is extracted with a perfluoro organic solvent having a high degree of fluorination (Novec 1230). And vice versa, BAS molecules with a high number of oxygen atoms (eugenol, eugenyl acetate) are extracted in a higher amount with a perfluoro organic solvent having a low degree of fluorination (Novec 7100).

At the last experimental stage, we carried out a study of eugenol yield by circulation method of extraction. The results obtained are presented in Figure 4.

As can be depicted from Figure 4, after $2 \mathrm{~h}$ of solvent circulation, the yield of eugenol achieved was $85 \pm 3 \%$ (eugenol yield relatively to PRM weight was $12.7 \pm 0.4 \% \mathrm{w} / \mathrm{w}$, and the yield of lipophilic substances relatively to PRM weight was $14.8 \pm 0.5 \% \mathrm{w} / \mathrm{w})$. Moreover, the yield of eugenol after 5 h was $87 \pm 4 \%$. From the graph, we can see that the optimal time of solvent circulation is within the range $1.75-2.5 \mathrm{~h}$ with an expected extraction yield of eugenol from 80 to $85 \%$.

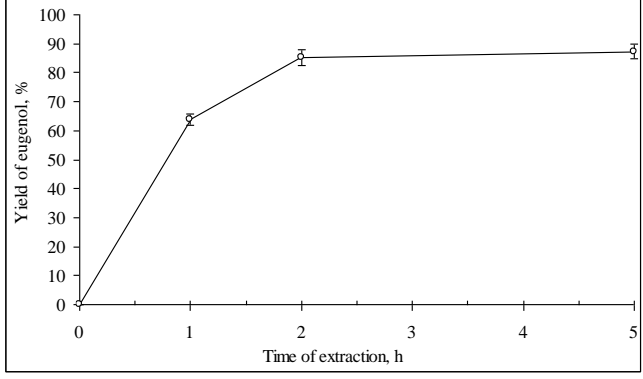

Figure 4.

Dependency of eugenol yield on the circulation time of Novec 7100 solvent. Repeat counts $n=3$ and significance level $\mathrm{p}=0.95$

The total content of eugenol in PRM (n-hexane) was $14.9 \pm 0.5 \% \mathrm{w} / \mathrm{w}$, and the content of lipophilic substances in PRM (n-hexane) was $18.2 \pm 0.6 \%$ w/w. These results were patented in Russia [4]. Under similar conditions, the yield of eugenol into the Novec 1230 solvent was $54 \%$ after $4 \mathrm{~h}$ of solvent circulation, which agrees with the abovementioned results that the degree of solvent's molecule fluorination and the presence of polar oxygen atoms have a significant influence on its extraction properties.

For the comparison of our technology with the extraction technology of eugenol from clove buds using super-critical and liquefied carbon dioxide, as 
well as freon 227 ea, the main results from different sources are given below.

Chatterjee D et al. presents the results on using supercritical carbon dioxide for the extraction of eugenol from clove buds: the yield was $129.86 \mathrm{mg} / \mathrm{g}$ of dried PRM equivalent to $98 \%$ of maximum yield in this study; the pressure was 250 bar; the temperature was $60^{\circ} \mathrm{C}$; the time of extraction was $90 \mathrm{~min}$ [6].

Kas'yanov GI et al. presents the results on using liquefied carbon dioxide: the yield of lipophilic substances was $18.0-20.0 \%$, the content of eugenol was $80 \%$, the pressure was 57 bar, and the time of extraction was $90 \mathrm{~min}$ [15].

Thus patent 2004/0105899 presented the results on using freon 227 ea: the yield of lipophilic substances was $9.59 \%$, the content of eugenol equivalent to peak area in the extract was $57.59 \%$, the pressure was 15 bar, and the time of extraction was $2 \mathrm{~h}$ [9].

As can be seen from the abovementioned results, the technology for eugenol/essential oil extraction from clove buds using perfluoro organic solvent Novec 7100 is easier and has almost an equal yield of eugenol/essential oil in comparison with technologies that use liquefied gases and supercritical carbon dioxide. As in this case, we need only relatively simple and low-cost Soxhlet extractor, where the refrigerant works at room temperature and normal atmospheric pressure to reduce the energy and cost for this technology. Moreover, along with ecological and toxicological parameters of the solvents, this technology seems to be eco-friendly and very promising for its development into an industrial scale.

Thus, using perfluoro organic solvents is a new and very promising technology that is simple in use and gives a high yield of the main essential oil components from PRM. Moreover, further research is very interesting to study the extraction properties of these solvents, determine their limits and forecast the possibility of extraction of different types of BAS from PRM.

\section{Conclusions}

The adequacy of the hypothesis about the possibility for extraction of the main essential oil components from clove buds with two different perfluoro organic solvents Novec 1230 and Novec 7100 was verified experimentally. The yield of main compounds of essential oil from clove buds into two different types of perfluoro organic solvents Novec 1230 and Novec 7100 was studied. The maximum yield of eugenol $81 \pm 4 \%$ was found to be for $n$-hexane by the method of simple maceration. The yield of eugenol for perfluoro organic solvent Novec 7100 was $73 \pm 4 \%$ and for Novec $12306.9 \pm 0.4 \%$. These results demonstrate that the yield of eugenol depended significantly on the degree of solvent molecule fluorination, the more fluorination the less eugenol yield. Using a circulation method for the extraction, it was found that the yield of eugenol was $85 \pm 4 \%$ after $2 \mathrm{~h}$ with the Novec 7100 solvent circulation. Under similar conditions, the yield of eugenol was $54 \pm 3 \%$ after 4 h of Novec 1230 solvent circulation. These results demonstrate high potential for use of some types of perfluoro organic solvents for selective extraction of lipophilic biologically active substances from the plant raw material and the necessity of research expansion in this field.

\section{Acknowledgement}

The results were obtained under state grant No. 12.6429.2017/BCh "Complex research of plant-origin objects in the process of creating targeted dosage forms for proctology".

Authors express their highest esteem and thanks to Dr. Sc. (Chem.), Prof. Mykola Blazheyevskiy of Physical and Colloid Chemistry Department, National University of Pharmacy, Kharkiv, Ukraine, for his help with the reference substance of eugenol.

\section{Conflict of interest}

The authors declare no conflict of interest.

\section{References}

1. Adefegha SA, Oboh G, Adefegha OM, Boligon AA, Athayde ML. Antihyperglycemic, hypolipidemic, hepatoprotective and antioxidative effects of dietary clove (Szyzgium aromaticum) bud powder in a highfat diet/streptozotocin-induced diabetes rat model. $J$ Sci Food Agric., 2014; 94(13): 2726-2737.

2. Ali S, Prasad R, Mahmood A, Routray I, Shinkafi TS, Sahin K, Kucuk O, Eugenol-rich fraction of Syzygium aromaticum (clove) reverses biochemical and histopathological changes in liver cirrhosis and inhibits hepatic cell proliferation. J Cancer Prev., 2014; 19(4): 288-300.

3. Banks RE, Smart BE, Tatlow JC, Editors. Organofluorine chemistry. Principles and commercial applications. New York: Springer, 1994.

4. Bojko NN, Zhilyakova ET, Pisarev DI, Novikov OO, Nefedova LV. Method for extraction of essential oil from clove tree buds. Patent RU 2696127 C1. C11B9/ 02 (2006.01). Pub. Date: 01.08.2019 (available in Russian).

5. Brunner G, Gas extraction. An introduction to fundamentals of supercritical fluids and the application to separation processes. New York: Springer, 1994.

6. Chatterjee D, Bhattacharjee P, Supercritical carbon dioxide extraction of eugenol from clove buds. Food and Bioprocess Tech., 2012; 6(10): 2587-2599.

7. Chemat F, Vian MA, Editors. Alternative solvents for natural products extraction. Green chemistry and sustainable technology. Berlin Heidelberg: SpringerVerlag, 2014.

8. Diego T, Santos DT, Meireles MAA, Extraction of volatile oils by supercritical fluid extraction: patent survey. Recent pat engineering, 2011; 5(1): 17-22.

9. Dowdle PA, Merseyside SSH, Corr S, Cheshire A, Harris H, Cheshire W, Solvent extraction process. 
Patent US 2004/0105899 A1. A61K 35/78. Pub. Date: Jun.3, 2004.

10. Flick EW, Editor. Industrial solvents handbook. $5^{\text {th }}$ ed. Westwood, New Jersey: Noyes Data Corporation, 1998.

11. Georgievskiy VP, Konev FA, Editors. Technology and standardization of drugs: Collection of research papers. Kharkiv: LLC "RIREG", 2000. (available in Russian).

12. Hatami T, Johner JCF, Zabot GL, Meireles MAA, Supercritical fluid extraction assisted by cold pressing from clove buds: extraction performance, volatile oil composition, and economic evaluation. J Supercrit Fluid., 2019; 144: 39-47.

13. Hemalatha R, Nivetha P, Mohanapriya C, Sharmila G, Muthukumaran C, Gopinath M, Phytochemical composition, GC-MS analysis, in vitro antioxidant and antibacterial potential of clove flower bud (Eugenia caryophyllus) methanolic extract. J Food Sci Technol., 2016; 53(2): 1189-1198.

14. Issac A, Gopakumar G, Kuttan R, Maliakel B, Krishnakumar IM, Safety and anti-ulcerogenic activity of a novel polyphenol-rich extract of clove buds (Syzygium aromaticum L). Food Funct., 2015; 6(3): 842-852.

15. Kas'yanov GI, Pehov AV, Taran AA, Natural food flavors - $\mathrm{CO} 2$ extracts. Moscow: Food industries, 1978. (available in Russian).

16. Ma M, Ma Y, Zhang G, Lia R, Jiang X, Yan X, Bie F, Li X, Lv Y, Eugenol alleviated breast precancerous lesions through HER2/PI3K-AKT pathway-induced cell apoptosis and S-phase arrest. Oncotarget, 2017; 8: 56296-56310.

17. Mittal M, Gupta N, Parashar P, Mehra V, Khatri M, Phytochemical evaluation and pharmacological activity of Syzygium aromaticum: a comprehensive review. Int J Pharm Pharm Sci., 2014; 6(8): 67-72.

18. Musthafa KS, Voravuthikunchai SP, Anti-virulence potential of eugenyl acetate against pathogenic bacteria of medical importance. Antonie van Leeuwenhoek, 2015; 107(3): 703-710.

19. Mukhopadhyay M, Natural extracts using supercritical carbon dioxide. $1^{\text {st }}$ ed. Boca Raton: CRC Press, 2000.

20. Nirmala MJ, Durai L, Gopakumar V, Nagarajan R, Anticancer and antibacterial effects of a clove bud essential oil-based nanoscale emulsion system. Int $J$ Nanomed., 2019; 14: 6439-6450.

21. State Pharmacopoeia of the Russian Federation. XIV ed. Vol. I. Moscow: Ministry of Healthcare of Russian Federation, 2018.

22. Tuma P, Tousignant L, Reducing emissions of PFC heat transfer fluids. SEMI Technical Symposium, 3M Specialty Materials, 1-8, San Francisco, CA, USA, 16 July 2001.

23. Vijayasteltar L, Nair GG, Maliakel B, Kuttan RIMK, extract of clove buds: Subchronic toxicity and mutagenicity studies. Toxicol Rep., 2016; 8(3): 439-449.

24. Woo JH, Ahn JH, Jang DS, Lee KT, Choi JH, Effect of kumatakenin isolated from cloves on the apoptosis of cancer cells and the alternative activation of tumor-associated macrophages. J Agric Food Chem., 2017; 65(36): 7893-7899.

25. Yuan YJ, Ning DS, Zeng RH, Ge FH, Study on extraction of clove bud by supercritical carbon dioxide and GC-MS analysis. Chin J Nat Medicines, 2007; 5(5): 363-365.

26. Zhilyakova ET, Novikov OO, Pisarev DI, Malyutina AY, Boyko NN, Studying the polyphenolic structure of Laurus Nobilis L. leaves. Indo Am J Pharm Sci., 2017; 4(9): 3066-3074. 